\title{
Influence of polymerization cycle in properties of acrylic resin polymerized by microwave energy
}

Fabrício Mezzomo Collares ${ }^{a}$, Carmen Beatriz Borges Fortes ${ }^{a}$, Vicente Castelo Branco Leitune ${ }^{a}$, Stefani Becker Rodrigues ${ }^{a}$, Susana Maria Werner Samuel ${ }^{a}$, César Petzhold ${ }^{a}$, Vater Stefani ${ }^{\mathrm{a}}$

\begin{abstract}
Objective: The purpose of this study was to evaluate the physicochemical properties of acrylic resin polymerized by microwave energy in short cycle of polymerization.

Methods: Two brands (Classico and VIPI) and two cycles were evaluated (manufacturer cycle and short cycle). The characteristics and properties as degree of conversion, glass transition temperature, impact strength-Izod, Knoop hardness, swelling degree, soluble fraction, specific mass, water sorption and solubility were evaluated.

Results: Glass transition temperature, hardness, specific mass, soluble fraction and solubility were statistically significant between cycles and brands $(p<0.05)$. Water sorption showed no difference between cycles $(p>0.05)$ and impact strength presented difference between brands in short cycle $(p<0.05)$. Acrylic resin polymerized by microwave energy with manufacturer cycle presented no difference in physicochemical properties between evaluated brands.

Conclusion: The short cycle of polymerization showed reduced properties in microwave acrylic resin when compared to manufacturer cycle. Manufacturer cycle of polymerization should be used to acrylic resin devices production.
\end{abstract}

Key words: Acrylic resins; Microwaves; Hardness test; Solubility

\section{Influência do ciclo de polimerização nas propriedades de uma resina acrílica polimerizada por microondas}

\section{RESUMO}

Objetivos: O objetivo desse estudo foi avaliar a influência do ciclo curto de polimerização nas propriedades físico químico de uma resina acrílica polimerizada por energia de microondas.

Métodos: Duas marcas (Classico e VIPI) e dois ciclos de polimerização foram avaliados (ciclo do fabricante e ciclo curto). As características e propriedades como grau de conversão, temperatura de transição vítrea, resistência ao impacto Izod, dureza Knoop, grau de inchamento, massa específica, sorção em água e solubilidade foram avaliadas.

Resultados: Temperatura de transição vítrea, dureza, massa específica, fração solúvel e solubilidade foram estatisticamente significantes entre os ciclos e marcas avaliados $(p<0.05)$. Sorção em água não apresentou diferença entre os ciclos testados $(p>0.05)$ e a resistência ao impacto no ciclo curto de polimerização foi diferente entre as marcas avaliadas $(p<0.05)$. Resinas acrílicas de microondas quando polimerizadas com o ciclo recomendado pelo fabricante não apresentaram diferença nas propriedades físicas químicas entre as marcas avaliadas.

Conclusões: O ciclo curto de polimerização resultou em propriedades reduzidas da resina acrílica de microondas quando comparadas com o ciclo recomendado pelo fabricante. O ciclo de polimerização recomendado pelo fabricante deve ser escolhido para confecção de aparelhos.

Palavras-chave: Resina acrílica; Microondas; Dureza; Solubilidade a School of Dentistry, Universidade Federal do Rio Grande do Sul, Porto Alegre, RS, Brazil b Organic Chemistry Department, Chemistry Institute, Universidade Federal do Rio Grande do Sul, Porto Alegre, RS, Brazil 


\section{INTRODUCTION}

The polymerization of acrylic resin starts by the decomposition of benzoyl peroxide molecule, resulting in two free radicals. This decomposition occurs with energy absorption, generated by heat, chemical reaction or microwave energy. In 1968 [1], the polymerization of acrylic resin by microwave energy was introduced. Polymerization process occurs in an electromagnetic field where molecules vibrate and rapidly change the direction resulting in intermolecular collisions and heat generation $[2,3]$. The heat is responsible for free radicals formation and the polymerization process initiation, and the MMA molecules connect to others by covalent bonds until the termination process $[2,4]$.

The microwave energy method was introduced in dental practice as an alternative to the conventional heat process method [5]. The acrylic resin polymerized by microwave energy showed similar properties to heat polymerized acrylic resin [6,7]. Microwave energy method provided low polymerization time without changing material properties when compared to heat polymerized method [8]. Consequently, polymer results at lower distortions with characteristics and properties as hardness, flexural strength and porosity were better or not different from heat acrylic resin [9] due to microwave method allows homogeneous heating.

Despite of acrylic resin polymerized by microwave energy presents lower polymerization time when compared to heat cycle, there are different cycles evaluated in literature [10]. The cycles range between 10 to 20 minutes of exposition, with different powers of microwave energy. Studies that compared experimental cycle and manufacturer cycles of polymerization showed that both cycles have no effect in the flexural strength that was provided by ISO 1567 (65 MPa) [11]. In literature, still not exist a consensus about properties as glass transition temperature, impact strength, hardness, swelling degree, specific mass, water sorption and solubility in short cycle of polymerization. Thus, the purpose of this study was to evaluate the physicochemical properties of acrylic resin polymerized by microwave energy in short cycle of polymerization.

\section{METHODS}

Two brands of acrylic resin polymerized by microwave energy were evaluated in this study: VIPI WAVE (Dental VIPI Ltda, São Paulo, SP, Brazil) and Onda Cryl (Artigos
Odontológicos Clássico Ltda, São Paulo, SP, Brazil). The color used was medium rose with nylon fibers. The composition and cycles of microwave acrylic resin are describe in Table 1.

\section{Degree of conversion}

The degree of conversion of specimens was evaluated using Raman spectroscopy. The degree of conversion was calculated as described in a previous study considering the intensity of $\mathrm{C}=\mathrm{C}$ stretching vibration (peak height) at $1650 \mathrm{~cm}^{-1}$, and using the $\mathrm{C}=\mathrm{O}$ stretching vibration at $1720 \mathrm{~cm}^{-1}$ from the polymerized and unpolymerized specimens, as an internal standard [12].

\section{Glass transition temperature}

Thermoanalytical behavior of acrylic resin was measured using a DSC system (DSC-4, Perkin Elmer, Beaconsfield, England). Approximately $10 \mathrm{mg}$ of each acrylic resin were weighed in an aluminum sample holder and then sealed with a press. Specimens were analyzed at a heating rate of $10^{\circ} \mathrm{C} / \mathrm{min}$ from $50^{\circ} \mathrm{C}$ to $190^{\circ} \mathrm{C}$ under a nitrogen atmosphere. The analysis was performed in triplicate, $n=3$. Two heating rate were realized and the glass transition temperature was established in the second rate.

\section{Impact strength-Izod}

The impact strength Izod test was performed according to ASTM D256 [13], except without slots. Ten specimens, with $64.00 \times 10.00 \times 3.00 \mathrm{~mm}( \pm 0.5 \mathrm{~mm})$ were analyzed with a universal testing machine (EMIC-AIC-1, São José dos Pinhais, Paraná, Brazil). The calculation of the impact strength Izod value was performed using the equation 1:

$$
\mathrm{Is}=[(\mathrm{Es}-\mathrm{Et}) / \mathrm{t}]
$$

where, Et - lost energy, Es - energy that determines the test piece breaks and $\mathrm{t}$ - thickness of the specimen, in meters.

\section{Knoop hardness}

To determine the Knoop hardness (KHN), specimens, (32.0 mm in length, $3.0 \mathrm{~mm}$ in width, and $10.0 \mathrm{~mm}$ in height, $\mathrm{n}=10$ ), for each group were polished in a polisher (Model $3 \mathrm{v}$, Arotec, Cotia, SP, Brazil) with a felt disc embedded in aluminium suspension (Alumina $1.0 \mathrm{~mm}$, Arotec, Cotia, SP, Brazil). The specimens were dried and stored

Table 1. Composition of acrylic resin polymerized by microwave energy and manufactured/ experimental cycles.

\begin{tabular}{|c|c|c|c|}
\hline \multirow{2}{*}{ Group } & \multirow{2}{*}{ Compound } & \multicolumn{2}{|c|}{ Cycles } \\
\hline & & Manufacturer & Short \\
\hline Onda Cryl (Classico) & $\begin{array}{l}\text { Powder: methyl methacrylate and ethyl acrylate copolymer, } \\
\text { butil ftalato, benzoyl peroxide and pigments } \\
\text { Liquid: methyl methacrylate monomer }\end{array}$ & $\begin{array}{l}3 \text { minutes with power of } \\
420 \mathrm{~W}, 4 \text { minutes } \\
\text { with no energy and } \\
3 \text { minutes of } 840 \mathrm{~W}\end{array}$ & \multirow{2}{*}{$\begin{array}{l}3 \text { minutes with power of } \\
560 \mathrm{~W}\end{array}$} \\
\hline VIPI WAVE (VIPI) & $\begin{array}{l}\text { Powder: methyl methacrylate polymer, benzoyl peroxide } \\
\text { and pigments } \\
\text { Liquid: methyl methacrylate monomer }\end{array}$ & $\begin{array}{l}20 \text { minutes with power of } \\
140 \mathrm{~W} \text { and } 5 \text { minutes } \\
\text { with power of } 420 \mathrm{~W}\end{array}$ & \\
\hline
\end{tabular}


at $37^{\circ} \mathrm{C}$ for $24 \mathrm{~h}$. Thus, the specimens were subjected to a microhardness test in which 5 indentations $(25 \mathrm{~g} / 10 \mathrm{~s})$, $100 \mu \mathrm{m}$ apart, were assessed using a digital microhardness tester (MICROMET ${ }^{\circledR}$, Bueller, Germany). The calculation of the hardness value was performed using the equation 2 :

$$
\mathrm{KHN}=\left[(14228 \mathrm{c}) /\left(\mathrm{d}^{2}\right)\right]
$$

where 14228 is a constant, $\mathrm{c}$ is the load in grams and $\mathrm{d}$ is the length of the longer diagonal in $\mathrm{mm}$.

\section{Swelling degree}

An analytical balance (SAE 2000, Bosch, Germany) was used to determine the initial dry mass $(\omega 1)$ of the specimens $(n=5)$. Then, each specimen was placed in a bottle containing $10 \mathrm{~mL}$ deionized water and stored at $37^{\circ} \mathrm{C}$. After 7 days, the specimens were dried with absorbent paper and weighed using analytical balance to obtain the swollen mass $(\omega 2)$. After that, the specimens were stored at $37{ }^{\circ} \mathrm{C}$ until there was stability of final dry mass $(\omega 3)$. The soluble fraction $(\omega \mathrm{s})$ for each specimen was calculated according to the following equation (3):

$$
\omega \mathrm{S}=(\omega 1-\omega 3) / \omega 1
$$

where $\omega 1=$ initial dry mass, $\omega 2=$ swollen mass and $\omega 3$ = final dry mass.

The volume fraction of the polymer, which was swollen in each specimen, was calculated by the equation 4 :

$$
\Phi=[(\omega 3 / \rho 3) /(\omega 3 / \rho 3+\omega / \rho)]
$$

where, $\omega_{3}=$ final dry mass, $\rho_{3}=$ specimen specific mass, $\omega=\left(\omega_{2}-\omega_{3}\right)=$ solvent mass absorbed by the polymer, $\omega_{2}=$ swollen mass, $\rho=$ solvent specific mass

The degree of swelling was calculated by inverse of the volume fraction of the polymer which was swelled in each specimen (5):

$$
\text { Degree of swelling }=1 / \Phi
$$

\section{Specific mass}

Specific mass $\left(\rho_{\text {specimen }}\right)$ was determined with analytical balance (SAE 2000, Bosch, Germany), by immersion of specimen in non solvent, according to ASTM 792-91 [14].

\section{Water sorption and solubility}

Water sorption and solubility were determined, based on the ISO 1567 [11]. Acrylic resin disks $(n=6)$ were produced in a polytetrafluoroethylene matrix $(50 \mathrm{~mm}$ diameter, $0.5 \mathrm{~mm}$ thick). Specimens were placed in desiccators containing silica gel and calcium chloride at $37^{\circ} \mathrm{C}$. The disks were repeatedly weighed after a $24 \mathrm{~h}$ interval in an analytical balance until a constant mass (m1) was obtained (e.g., until the mass loss of each specimen was not more than $0.0002 \mathrm{~g}$ in any $24 \mathrm{~h}$ period). Diameter and thickness of each specimen were measured with a digital caliper to calculate the volume (V) of each disk (in $\mathrm{mm}^{3}$ ). Thereafter, the specimens were stored in sealed glass vials with $50 \mathrm{ml}$ of deionized water at $37^{\circ} \mathrm{C}$ for 7 days. After seven days, the disks were weighed to obtain a mass (m2) and then returned to the dissector. Next, the specimens were weighed until a constant mass (m3) was obtained (as described above). Water sorption (WS) and solubility (SL), in micrograms per cubic millimeter, were calculated using the formulae (6):

$$
\mathrm{WS}=[(\mathrm{m} 2-\mathrm{m} 3) / \mathrm{V}] \quad \mathrm{SL}=[(\mathrm{m} 1-\mathrm{m} 3) / \mathrm{V}]
$$

\section{Statistical analysis}

Characteristics and properties (impact strength Izod, hardness, glass transition temperature, swelling degree, specific mass, water sorption, solubility and dynamic mechanical analysis) were performed using one-way ANOVA and Tukey's post-hoc test, with 0.05 being the level of significance.

\section{RESULTS}

Degree of conversion values of microwave acrylic resin in manufacturer cycle were $88 \%$ and $89 \%$, and in short cycle were $72 \%$ and $70 \%$ for Onda Cryl ${ }^{\circledR}$ and VIPI WAVE ${ }^{\circledR}$, respectively. Results of properties and characteristics are shown in Table 2. Glass transition temperature, hardness, specific mass, soluble fraction and solubility were statistically significant between cycles and brands $(p<0.05)$ for manufacturer cycle. Water sorption showed no difference between cycles $(\mathrm{p}>0.05)$ and impact strength presented difference between brands in short cycle $(\mathrm{p}<0.05)$.

Table 2. Properties and characteristics of acrylic resin polymerized by microwave energy for manufactured and short cycle.

\begin{tabular}{lcccc}
\hline \multicolumn{1}{r}{ Properties } & \multicolumn{2}{c}{ Manufacture cycle } & \multicolumn{2}{c}{ Short cycle } \\
& Onda Cryl & VIPI WAVE & Onda Cryl & VIPI WAVE \\
$\mathrm{Tg}\left({ }^{\circ} \mathrm{C}\right)$ & $103.4 \pm 0.9^{\mathrm{a}}$ & $103.0 \pm 1.0^{\mathrm{a}}$ & $91.2 \pm 2.1^{\mathrm{b}}$ & $91.1 \pm 3.9^{\mathrm{b}}$ \\
$\mathrm{IS}(\mathrm{J} / \mathrm{m})$ & $98.3 \pm 9.7^{\mathrm{a}}$ & $97.2 \pm 9.9^{\mathrm{a}}$ & $59.4 \pm 12.3^{\mathrm{b}}$ & $48.9 \pm 13.3^{\mathrm{c}}$ \\
$\mathrm{KHN}$ & $21.0 \pm 0.7^{\mathrm{a}}$ & $21.3 \pm 0.7^{\mathrm{a}}$ & $19.4 \pm 1.3^{\mathrm{b}}$ & $19.6 \pm 1.3^{\mathrm{b}}$ \\
$\rho\left(\mathrm{g} / \mathrm{cm}^{3}\right)$ & $1.19 \pm 0.00^{\mathrm{a}}$ & $1.19 \pm 0.00^{\mathrm{a}}$ & $1.16 \pm 0.00^{\mathrm{b}}$ & $1.16 \pm 0.00^{\mathrm{b}}$ \\
$\omega \mathrm{s}(\mathrm{g})$ & $4.4 \times 10^{-4} \pm 0^{\mathrm{a}}$ & $4.5 \times 10^{-4} \pm 0^{\mathrm{a}}$ & $8.4 \times 10^{-4} \pm 0^{\mathrm{b}}$ & $8.8 \times 10^{-4} \pm 0^{\mathrm{b}}$ \\
$1 / \Phi$ & 1.02 & 1.02 & 1.02 & 1.02 \\
$\mathrm{WS}\left(\mu \mathrm{g} / \mathrm{mm}^{3}\right)$ & $24.1 \pm 1.6^{\mathrm{a}}$ & $23.3 \pm 1.7^{\mathrm{a}}$ & $25.8 \pm 2.8^{\mathrm{a}}$ & $25.3 \pm 2.5^{\mathrm{a}}$ \\
$\mathrm{SL}\left(\mu \mathrm{g} / \mathrm{mm}^{3}\right)$ & $0.8 \pm 0.1^{\mathrm{a}}$ & $0.9 \pm 0.1^{\mathrm{a}}$ & $1.4 \pm 0.1^{\mathrm{b}}$ & $1.5 \pm 0.1^{\mathrm{b}}$ \\
\hline
\end{tabular}

Different small letter indicates statistical difference in same row $(p<0.05)$. Tg - glass transition temperature; Is - impact strength; KHN - Knoop hardness; $\rho$ - specific mass; $\omega$ s - soluble fraction; $1 / \Phi$ - swelling degree; WS - water sorption; SL - solubility. 


\section{DISCUSSION}

The effect of different microwave energy intensity and time of cure influenced in mechanical properties of microwave acrylic resin. The decrease of time in cycle of microwave energy is beneficial to decrease the work time and energy consumption. On the other hand, lower time of activation of acrylic resin resulted in polymer with low mechanical properties.

The degree of conversion of monomer to polymer showed different values between two cycles of polymerization. This difference is due to the polymerization process of material. The short cycle has high power in short period, probably, the amount of free radicals was not sufficient to form a large number of polymer chains, and the heat was not homogeneous inside the material, which reduces its degree of conversion. Beyond these reasons, it was observed that the polymer cured in short time and with high power showed porosity that can be related to the volatilization of uncured monomer [5].

Lower degree of conversion and presence of pores resulted in decreased mechanical properties [15]. In this study, more time of polymerization with less power resulted in the increase of impact strength Izod and degree of conversion. The acrylic resin Onda Cryl presented greater value of impact strength Izod than VIPI Cryl, in short cycle. Probably, this difference occurs due to the composition of acrylic resin. Even with this difference, polymers cured in short cycle presented more porous in polymer which contributed to low impact strength Izod. Short cycle also showed decreased specific mass related to increase of porous in formed polymer.

Knoop microhardness and $\mathrm{Tg}$ showed no difference between brands in the same type of cycle. In spite of, when cycles were compared, they showed statistical difference $(p<0.05)$, where manufacturer cycle presented high value. Low Tg value demonstrated that this polymer presents lower crosslinking $[16,17]$ despite presented similar values of swelling degree.

Results of water sorption and solubility were in accordance to the parameters of the ISO 1567 [11] for all brands and cycles. However, solubility of short cycle showed increased values compared to manufacturer cycle of polymerization. These results confirm with increase of soluble fraction and decreased specific mass results, since occurred increase of porous in polymer. The short cycle increased solubility and the amount of porous that resulted in plasticization of polymer, decrease of mechanical properties like color stability and longevity of polymer. Whereas, the swelling degree and water sorption in short cycle presented no difference of manufacturer cycle.

The polymerization cycle influenced the properties of microwave acrylic resin, independently of brands evaluated. Manufacturer cycle showed improve of polymer properties as degree of conversion, Tg, impact strength, Knoop hardness, soluble fraction, specific mass and solubility, than short cycle (3 minutes at $560 \mathrm{~W})$. Acrylic resin polymerized by microwave energy needs more time of heating with low power to result in polymer with increased properties.

\section{CONCLUSIONS}

Acrylic resin polymerized by microwave energy with manufacturer cycle presented high physicochemical properties when compared to short cycle, independent of the brands evaluated. In this study short cycle of polymerization resulted in polymer with lower properties. Manufacturer cycle of polymerization should be used to acrylic resin devices production.

\section{REFERENCES}

1. Niishi MJ. Studies on the curing of denture base resins with microwave irradiation with particular reference to heat-curing resins. Osaka Dent $1968 ; 2: 23-40$

2. Nevalainen MJ, Närhi TO, Ainamo A. Oral mucosa lesions and oral hygiene habits in the home-living elderly. J Oral Rehab 1997; 24:332-7. https://doi. org/10.1046/j.1365-2842.1997.d01-298.x

3. Silva $\mathrm{CHL}$, Paranhos HFO, Ito IY. Evidenciadores de biofilme em prótese total: avaliação clínica e antimicrobiana. Pesqui Odontol Bras 2002 16:270-5. https://doi.org/10.1590/S1517-74912002000300015

4. Barbachan JJD, Rados PV, Sant'Ana Filho M, Domingues MG. Estudo clínico da estomatite protética: avaliação preliminar. Rev Fac Odontol Porto Alegre 1995; 36:27-31

5. Ilbay SG, Guvener S, Alkumru HN. Processing dentures using a microwave technique. J Oral Rehabil 1994; 21:103-9. https://doi. org/10.1111/j.1365-2842.1994.tb01129.x

6. Reitz PV, Sanders JL, Levin B. The curing of denture acrylic resins by microwave energy. Physical properties. Quintessence Int 1985; 16: 547-51.

7. Shlosberg SR, Goodacre CJ, Munoz CA, Moore BK, Schnell RJ. Microwave energy polymerization of poly(methyl methacrylate) denture base resin. Int J Prosthodont 1989; 2:453-8.

8. Tsuchiya H, Hoshino Y, Tajima K, Takagi N. Leaching and cytotoxicity of formaldehyde and methyl methacrylate from acrylic resin denture base materials. J Prosthet Dent 1994; 71:618-24. https://doi.org/10.1016/00223913(94)90448-0

9. Barbosa DS, Pero AC, Marra J, Compagnoni MA. Flexural polymerized by different strength of acrylic resins cycles. J Appl Oral Sci 2007; 15:424-8. https://doi.org/10.1590/S1678-77572007000500010

10. Compagnoni MA, Barbosa DB, de Souza RF, Pero AC. The effect of polymerization cycles on porosity of microwave-processed denture base resin. J Prosthet Dent 2004; 91:281-5. https://doi.org/10.1016/j. prosdent.2004.01.006

11. ISO 1567:1999 Dentistry- Denture Base Polymers. Switzerland; 1999.

12. Shin, W. S., Li, X. F., Schwartz, B., Wunder, S L., \& Baran, G. R. Determination of the degree of cure of dental resins using Raman and FT-Raman spectroscopy. Dental Materials 1993; 9:317-24. https://doi. org/10.1016/0109-5641(93)90050-Z

13. ASTM-International. American society for testing and materials. D 256 Izod Impact. United States of America. 1998.

14. ASTM-International. American society for testing and materials. IN 153 Density. United States of America. 1998.

15. Keller JC, Lautenschlager EP. Porosity reduction and its associated effect on the diametral tensile strength of activated acrylic resins. J Prosthet Dent 1985; 53:374-9. https://doi.org/10.1016/0022-3913(85)90516-5

16. Anseth KS, Bowman NC. Kinetic gelation model predictions of crosslinked polymer network microstructure. Chem Eng Sci 1994; 49:2207-17. https:// doi.org/10.1016/0009-2509(94)E0055-U

17. Tamareselvy K, Rueggeberg FA. Dynamic mechanical analysis of two crosslinked copolymer systems. Dent Mater 1994; 10:290-7. https://doi. org/10.1016/0109-5641(94)90036-1 